621.822 .87

\title{
円すレころ軸受にまけるニ, 三の問題()
}

\author{
金子鍊 造(2) 杉崎治三郎(3)
}

\section{緒}

円すいとろ軸受の特色とするところは，1個の軸受 で半径打よび軸両方向の荷重を同時に受け得るところ にあり，かつその負荷容量はころがり軸受中最も大き いとされている。

しかしながら一方仍いてての種軸受の最も大きな 欠宿は，いうまでもなく摩擦モーメントが他のころが り軸受に比べて大きいとと，扔よび高速回転に対して 不向きとされている点にある。すなわち円すいころ軸 受は回転に際し温度上柔は玉軸受の 2 倍程度に上り, $\mathrm{DN}$ 值 30万以上に颃いては往々にして焼付きさえ起す

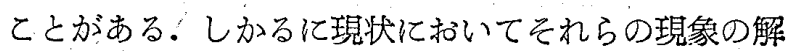

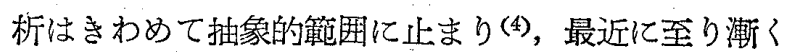
各方面で活発な研究(5)(6)(7)が進められる機運に立ちい たったとはいうものの，いまだ決定的な結論を得るに は至っていないように見受けられる。筆者もかねて 円すいてろ軸受の品質向上に関する研究を行っていた が，たまたま内輪䓩内つばの動的特性を試験する過程 に扔いてやや與味ある二，三の現象に接したので，て てにその解説をのべ今後の円すいてろ軸受の設纾打よ び加工に対する参考に供する次第である。

\section{1. 円すレころ軸受の摩㨲特性}

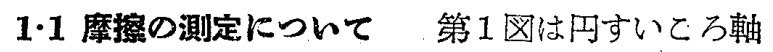
受にスラスト荷重を与えて運転するための軸受試験装 置である。摩擦モーメントの測定はてれ宣亩接測定す。 る適当な装置がなかったため，外輪の温度上昇を測る ことにより軸受の回転中の摩察による発熱量を求め, てれによって摩摖を表わす方沠を採用した。韩受温度 と発生熱量との関係を求めそために, 第 1 困の供試軸

(1) 原稿受付 昭和 28 年 9 月 21 日.

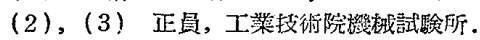

（4）たとえば W.Jürgensmeyer, Die Wälzlager. まねは Michell, Lubrication.

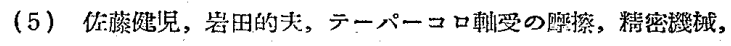
15 巻 189 卢, 1950.

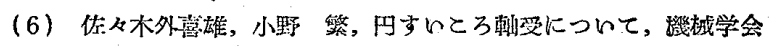
諭交集, 17 巻 59 最, p. 16, 昭 26.

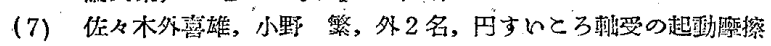

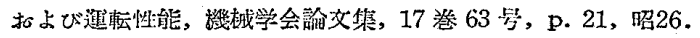

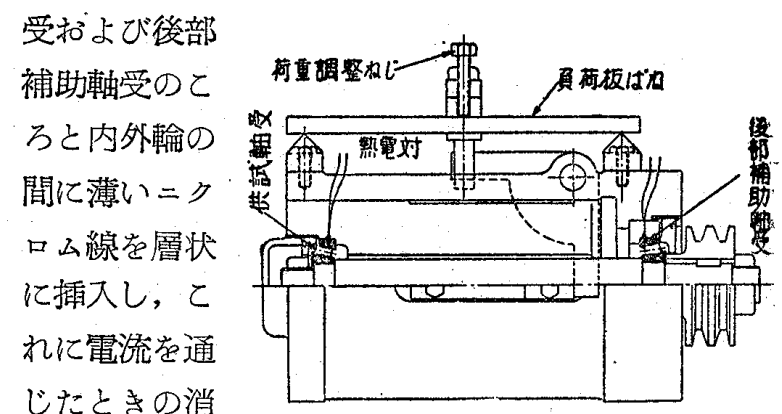

じたときの消

費電力之外輪 温度の関係を あらかじめ調 べて扣き，笑 際の運転中に おける温度上 昇を知れば直 接低試軸受の 発生熱量がわ かるようにし た。したがっ て運転装置の 形状扣よび㓐 容量等による 実験誤差は， 試験に必要な 程度において

はこれをのぞくてとができるものと考える．第2図は 後部補助軸受の温度を笑際の運転時の温度範囲内で種 々に変えたときの供試軸受の温度と発生熱量の関係を 求めたときの測定結果であり, 発生熱量と温度との関 係は後部軸受の温度のいかんにかかわらずほとんど比 例的関係にあることがうかがわれる。な打図中に示す 数值は，後部軸受がそれに相当する荷重を受けたとき に示す温度上杽と等しくなるような電力を与えた状態 の下で供試軸受の発熱量と温度上景の関係を求めたも のであり，てれによって後部軸受の温度の影響が測定 の誤差になるてとを避けるてとができる。また喾温の 変化による放篹係数の変化の影響は同一低試彰受の試 験を異なる案温の下で数回行うことにより補正曲線を 
求めて笑験值を修正するようにした。

$1 \cdot 2$ 測定結果，第 3 図は上記の方法により供試軸 受回転数 $700 \mathrm{rpm}$.に扔ける発生熱量と軸受荷重の関 係を測定した ときの測定例 である.な抏 このときの供 試軸受は, 30206 (内径 $30 \mathrm{~mm}$, 外径 $62 \mathrm{~mm}$ ) であ り温度上算は 始動後約 2 時 間で定常状態 澾した。図 亿示す 4 本の 曲線はおのお の軸受中のこ ろ数を变えた

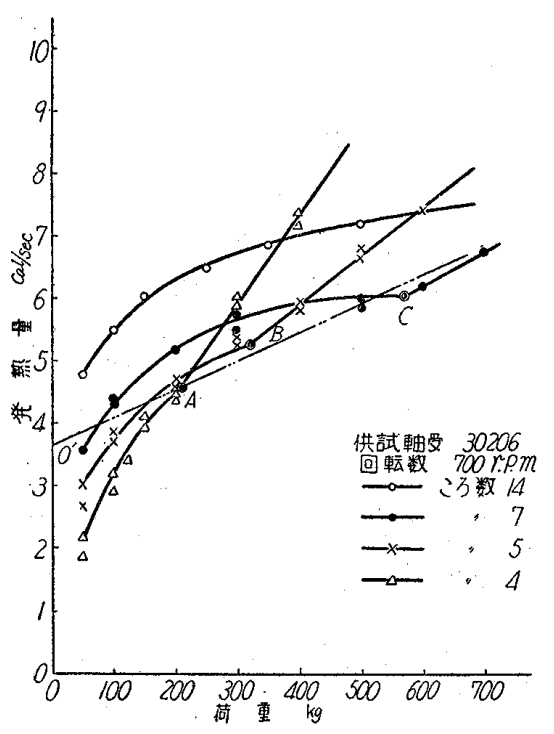

第 3 図
ときの測定結果である．四に示すようにてろ数か減少 すれば低荷重のときは発熱が少々，高荷重のときは逆 に発熱が急激に増加するのが認められる。乙の傾向は すべての円すいころ軸受について同じであり，DN 值 25 万の之きる同じような結果が得られている。

$1 \cdot 3$ 測定結果に対する考察 A. 測定結果の解析に ついて 第 3 図の曲線はいずれも初期は典形的な連 続 2 次曲線の形を示し， ある荷雷以上で急激な変化を 起すような変曲点が存在する，初期に示す 2 资曲䠌は 最近に㧈ける円筒のころがり摩擦理論( ${ }^{(8)}$ 亿述べられて いるように，摩擦は䩜受荷央の平方限に比例すると考 えれば，乙の傾向は一応簡単に説明し得られる。しか しながらこれは供試軸受が完全にてろがり接触のみ行 っている場合のことであり，本試験のように大きなス ラスト荷重加㗢いている場合は, 当然内輪案内つばと てろ端面間にすべり摩擦が生じており, 接触王力に比 例した発等が上の曲䠌に含まれていると考えなければ ならない。

いま内輪と 1 個のころの間に作用する力を $P_{i}$, 同様 に外輪と乙ろの聞の力を $P_{0}$, 内輪つばとこ万端面の間 の力居 $P g$ とし, 比例定数を扔の扔の $K_{1}, K_{2}, K_{3}$ と すれば，軸受の回転中に和ける発生熱量 $Q$ は

$$
Q=K_{1} \sqrt{P_{i}} \cdot Z+K_{2} \sqrt{P_{0}} Z+K_{3} P g \cdot Z
$$

ただし $Z$ : 朝受中のころの数, $K_{1}, K_{2}, K_{3}$ : 軸受の 形状, 回転数，䔸の仕事当量等により定まる 定数

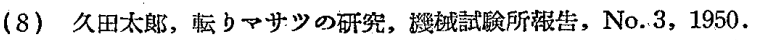

によって表わされる。

一方第 3 図の変曲点について考えて見る. 变曲点に 扣ける軸受荷重，扣よ゙びそのときに内輪とてろの間に 作用する力, そのときの接触面に扔ける最大応力の関 係は第1表のごとくなる。

第 1 表

\begin{tabular}{|c|c|c|c|}
\hline とろ数 & $\begin{array}{r}\text { 変曲点荷重 } \\
\text {. }\end{array}$ & $\begin{array}{l}\text { 有蕍ところ } 1 \text { 佔 } \\
\text { に働く力 } \mathrm{kg}\end{array}$ & $\begin{array}{l}\text { 最大芯力 } \\
\times 10^{2} \mathrm{~kg} / \mathrm{cm}^{2}\end{array}$ \\
\hline 3 & 200 & 275 & 192 \\
\hline 5 & 325 & 269 & 190 \\
\hline 7 & 560 & 331 & $210^{\circ}$ \\
\hline 14 & - & $\ldots$ & - \\
\hline
\end{tabular}

すなわち変曲点に打ける最大応力はいずれ害験誤 差の範囲に揖いてほぼ同一と見なすてとができる。し 加も変曲点に打ける内輪とてろの間の応力は，その值 が軸受材質の弾性限界にきわめて近い值であり，一店 弾性限界説(8)による説明が妥当の上うに考光られる。 すなわち変曲点以上の荷重に抽いては軸受はその接触 部が塑性変形をなして扔り, 荷電の増加に伴い摩擦力 が急激に增加するものと説明し得られる。しかしなが ら第 1 表の最大応力僬はいずれも軸受鋼の弾性限界值 より幾分小さいととは事実であり，てれについては後 述するようにてろの倒れ，扣よび転走面の加工精度に よっててれを説明することができる。

変曲点に扣けるころ, 内外輪間の荷重を扣の打の $P_{i c}, P_{0 c}, P_{g c}$ とすれば (1) 式より変曲点の摩擦 $Q_{c}$ は

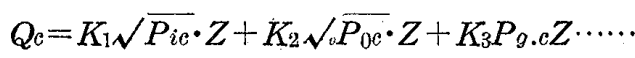

しかして変曲点においては上述のようにてろ数に無関 係に I個のころに同一の力が作用していると考えられ るから

$$
K_{1} \sqrt{P_{i c}}+K_{2} \sqrt{P_{0 c}}+K_{3} P_{g . c}=K .
$$

は一定値となり，(2) 式は

$$
Q_{s}=K \cdot Z
$$

すな方ち变曲点に扔ける摩擦仕事はこう数に比例す ることになる。

したがって上述の推定のように，円すい部は純粋な ころがり接触，つば部は純粋なすべり接触をなし，か つ各部の作用力の分布が円すいこ万軸受の幾何学的形 状のみによって定まるような簡単な分布をしているも のと仮定すれば，第 3 図の変曲点 $A, B, C$ を緢ぶ值 線は座標の原点を通過しなけれぱならないととにな る: しかし図们明らかように上記のととがらは実際 には成立して扔らず $A, B, C$ 等結ぶ直線は $O^{\prime}$ で縰 軸と交わっている.

これらの原因として当然保持器とてろの間のすべり 
摩擦，打よび閏滑油による流体摩擦等の因子を考えな ければならないが，乙の量は低速回転に扣いては一般 にきわめて小さいものとされて和り，てれによって上 記の現象のずれを説明するととは到底不可能である。

B.円すいころの運動について その 1. したがっ て円すいてろ蟿受に扣いては上記のような純精な運動 はあり得ないと考えなければならない。したがって純 䊉なころがり証実は何分かのすべりを伴ったものと考 える外なく，その最も大きな可能性として軸受国徂中

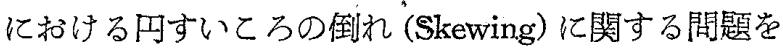
考える必要が生じて来た。

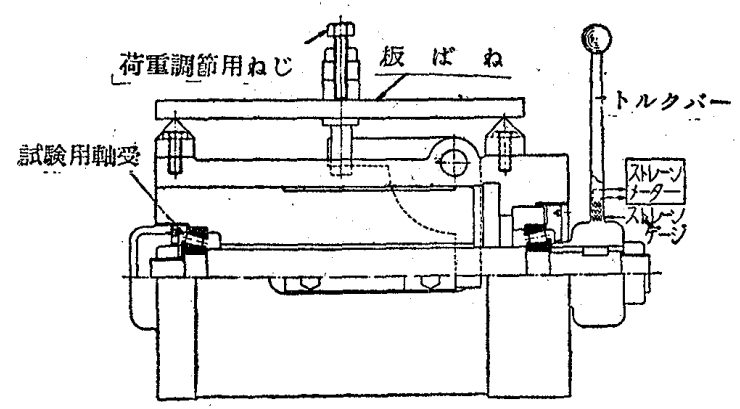

第 4 図

第 4図にころの倒れの傾向を求めるために用いた装 置を示す，この測定方法の原理とする所は。軸受を前 述の試験状態と同じうに組み込み，定められた方向 そ静かに回転させ，ある角度回転したとき急に逆方间 に回転を変えてやる。にのときもしてろが幾分か倒さ れているとすれば，逆転の過程に执いて必ずとろは正

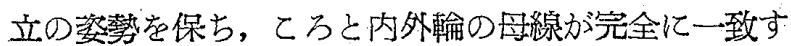
る瞬間があるととになり，その時の摩摖力は最低值を 示すことが推定できる。この装置では上記の摩撜方の 変化をトルクバーと抵抗 䠌ひずみ訐とよって測㱏 乙, 測定結果の一例第 5 図に示す，図Aは円す いこら軸受，図Bは五軸 受に対する測定結果であ る。図に明らかなように 円すいころ軸受に招いて は逆転の初期にころの倒 れがきよう正され，回転 が進むに彷っててろの倒
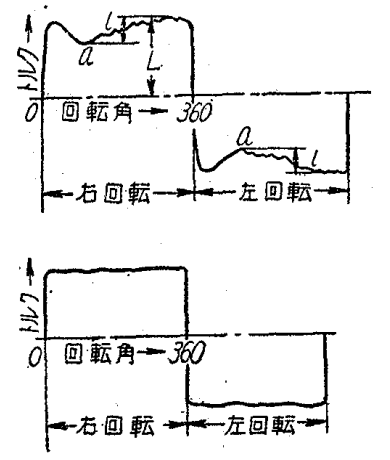

第 5 図 れが大きくなり，摩擦トルクが除々に增加して行くの が認められるが，五軸受に打いては回転方向の変化に よる摩摖トルクの変動は全々認められない.したがって 第 5 図Aの $l$ と $L$ 比はころの倒れが蟿受の摩丞に影 響する割合を示すものと考えてさしっかえないてとに

なる・第6図 はころ数を 3 , $5,7,14 \bigcirc 4$ 段に変えたと きの $l / L の$ 値 学荅荷雷住対 して測定した 場合の例で ある. 曲線证 いずれも前述 の変曲点に相 当する荷重に 抽いて最大傎 走示している が，乙れは前 述のごとく変 曲点より上で 軸受摩矮が急 激に堌加して も，ころの倒 れは依然とし て荷重に対し 連綕的な增加 を示すに止ま るとと表わ している。

第7园は円 すいとろ蒀受

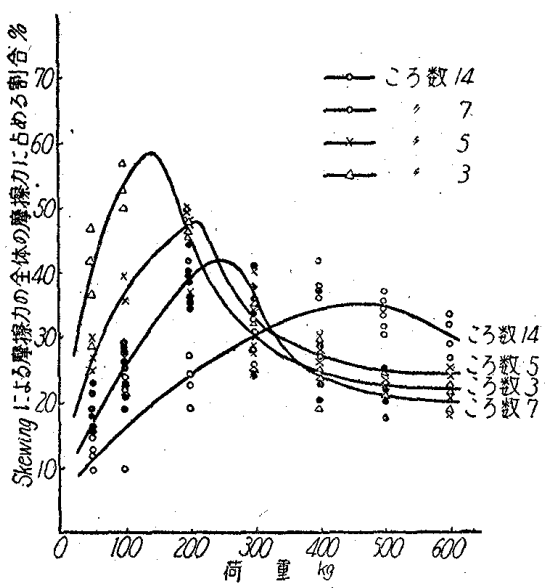

第 6 㘡

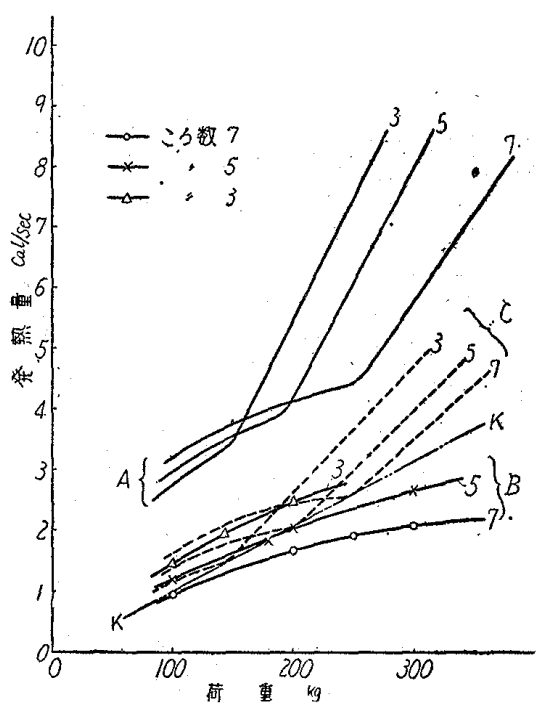

第 7 図
の全体の摩㻮特性曲線群 $A$ (第1図に示方方法による 測定結果）に対し，面述の測定法により求めたてろの 倒れによる摩擦值 $B$ とを対比して表わしたものであ り，两者の差がころの倒れの全くないときの軸受の理 想的な摩祭特性 $C$ (点線)を示すとと亿なる。

この場合前述のように $Q=K \cdot Z$ の仮定についての 変曲点の傾向を見ると，図の $K-K$ 直線に示すように 三つの変曲点は怙の打の一直線上にあり，しかもこの 直線は座標の原点 $O$ 点通り上記の推定はほぼ妥当で あるように考えられる。

C. ころの倒れについて その2. 上述のようにて ろの倒れの影響ば荷重が大きいほど大きく，乙万正常 個数(14 個) のとき $30 \%$ 亿も澾する.

ころの倒れに関係する囚子の内，最も注意しなけれ ばならないととは，ころ，内輪，外輪三者を組合せた ときの円すい頂点の不一致によるすべりにもとづくこ うのこじれであるが，精密測定(9)による頂点の食い違

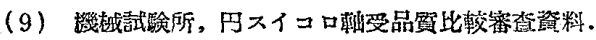


いの影響の試験の結果に よれ《゙第8図の $O O^{\prime} \pm 0{ }^{\circ} 1$ $\mathrm{mm}$ の範团に和いては何 らの差異をも認めるてと ができなかった。てれは もち万んての量がきわめ て大きい場合㹥当然夫き な影響を及代すととであ 万うが(10)，現在の製作精 度の範团ではさほど開題 にする必要はない。

第 9 図，第 10 図はこ
第 8 目
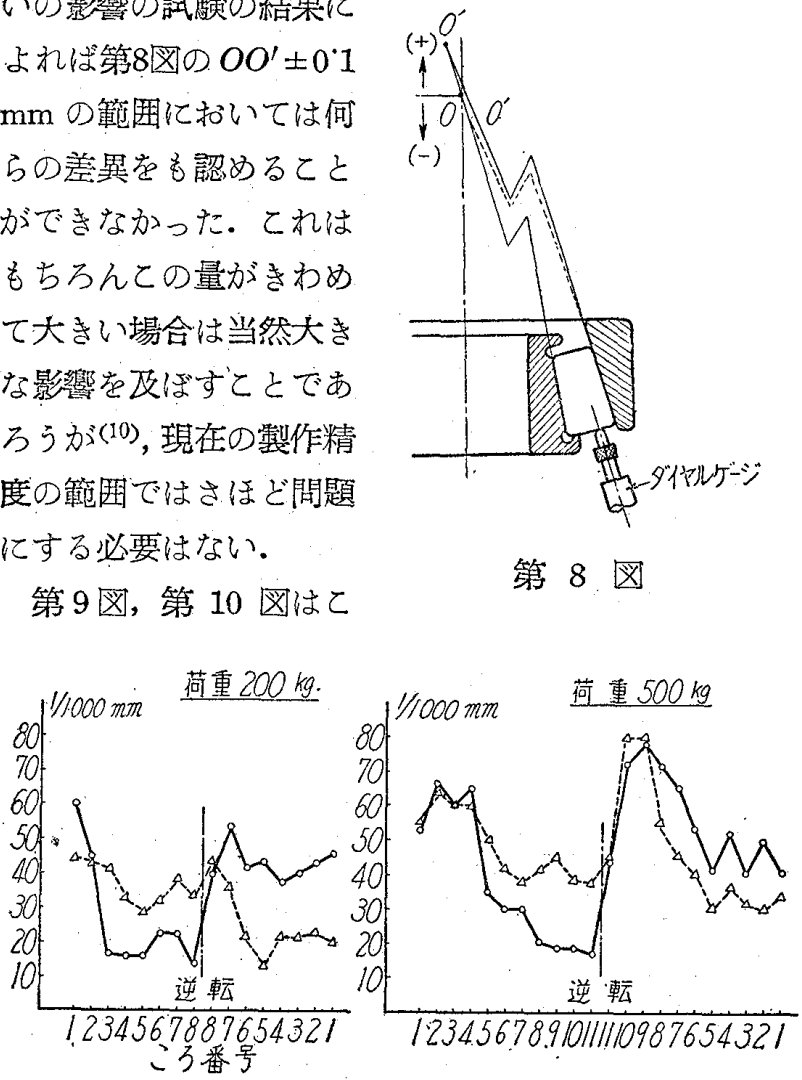

第 9 度

ろの端面に第

8 闵のように

ダイヤルゲー ジを当て，軸

受学国転させ たときのとろ 大端面の高さ をその左扣よ び右端につい て測定した結 果である.第 9 図，第 10 図の笑線は右 端の値, 点線 はそれに相当

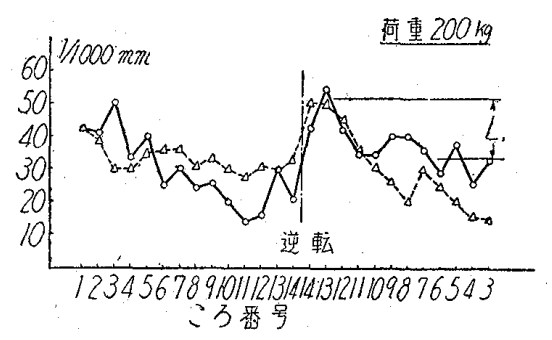

する左端の読みであり，てろが倒れないで回転して抏 れば当然この曲線は一致しなければならない。したが ってての測定結果に示すように右端の高さと，古端の 高さが各ころに﨎し異なっている場合はてろはその量 だけ傾斜していると洘えられる。この方法は学体とし ての軸受の試験についてかって推奖した方洗(11) であ

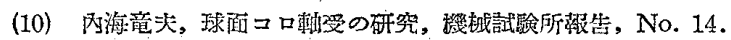

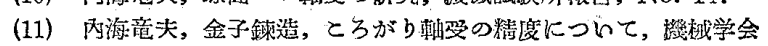
誌, 55 巻 399 骂, p. 247 , 昭 27 .
るが，乙の場合は第1図の装置に組込んだ軸受に対し て行った。禹図とも1番目のてろは左右の読みがよく 一致して打りころの倒れがないてとを示している が，軸受が回転するに從いだんだんととろが倒れてい る上うすがかかる。また逆転の衫期にてろの倒れがき よう正され再び上と同一経過をたどりててろが反珓側 亿倒れて行く過程もうかがわれ，トルク变動礼いて 推定されたてろの倒れときわめてよく一致する。

この試験結果䎲よれば，いずれもころの倒れる布向 は一定してて扔り，回転方向に対しころ大端側が進んだ 位置をとる。したがっててろは軸受の回䎐に伴い自転 軸に直危な方向へ運動し，除々に外輪の内部にもぐろ うとしている．第 10 図の $L_{1} ， L_{2}$ は扰の括のてろが もぐり込んだ量を表わして扣り，ての值はまた内輪端 面が軸方向に動いた量に一致しているととがわかっ た。したがってての測定綪果によれば，軸受は回転す るととによりてろ，内輪は二体となって外輪の中にも ぐり込み，いわゆるこじれによる余分の荷重の増加を 来していると考えなければならない。したがって前述 のごとくトルク柱当然增加し，汃逆転の初期偮小 のトルクを示すてとも十分説明できる.

またてろの倒れの原因はつば部ところ端面の間に衝 〈摩擦力と内外輪ところの円すい部の最大接触応力の， 位置によって 定まる。第11 困は内輪と乙 万の按触方

$A, B$ のよう な二つの極端 な当りを示す ような場合の
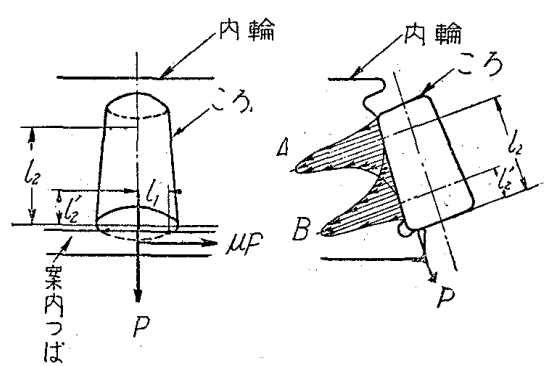

第 11 図
軸受に扔けるころに作用するモーメントの大きさを表 わした解説図であり，案内つばとこら端面の摩擦係数。 を片をすれば，ころに作用する倒れのモーメントは $A$ の場合 $\mu \cdot P \cdot l_{2}, B$ の場合は $\mu P l_{2}^{\prime}$ となり $B$ のーメン の方が小さい，第 10 図は $B$ の按触のときのもので あるが，A型(第9図)のものよりてろの倒れの小さい てとがわかる。したがって大ま加教光ててらと内外 輪の当りは大端近い方で強了当る方がころの安定を期 するてとができそうである。

上記のてとはきわめて極端な例纪ついての試験結果 であり，とろの倒れに関係する因子は必ずしも上述の ような簡単なものでは梦々，軸受部品の精度はも台る んのこと，軸受の取り゙うけ精度，軸受箱の精度等が大 きな影響を不ばしているてとはいうまでもないが，こ れらの関係についてはまだ明確な結諭を得ていない。 


\section{2. 円すレころ軸受の摩㮩の分析}

上述により軸受全体としての摩䌨特性の傾向は明ら かとなったが，ててでは円すい部(てろがり接触部)と つば部(すべり接触部) との摩㻮の分布について考えて みる。

\section{$2 \cdot 1$ 測定装置まよび測定結果 （1）式加ら直接計} 算によっててろがりとすべりの関係を求めるてともで

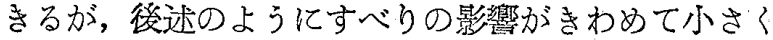
わずかな実殷誤差も間題となるため，直接測定から求 める方洗を採った。第12図にその装置を示す。

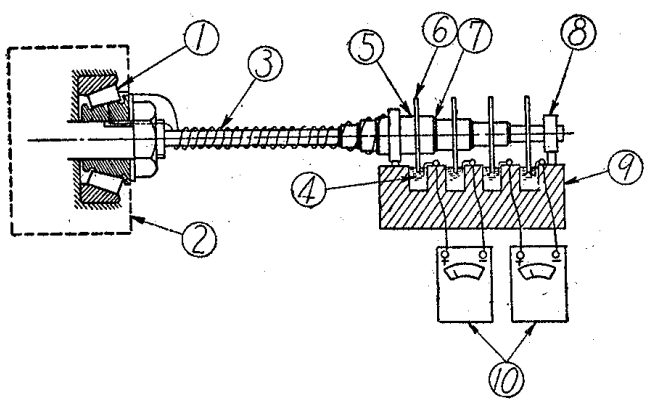

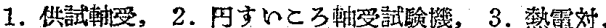

4. 水銀，5.クロームめつき世る铜管，6. 敛裂つば，

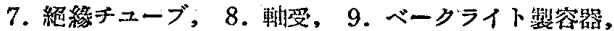

10. シリボルトメータ.

第 12 目

すなわち供試軸受の内輪に放䉓加工によりつば部と円 すい部に表面近くまで細い穴を明け，乙れ认薙電対を そう入し，単時間運檕に和ける和の扣のの温度上景を 湘定した．運転特間としては 15 秒をとったが，ての 程度なら熱伀導の影響をさけるととができると洘え た。また発熱量は温度と表面積の相乗に比例するもの とし，との場合は円すい部とつば部の表面積の比を14

：1とし，円すい部の温度のみを 14 倍しててれを発 薙係数と仮称して第 13 困に表わした. 第 13 図の結 果は円すい部とつば部の発熱と荷重の関係をもとも 結果である。

$2 \cdot 2$ 測定結果に対する考察 第 13 困によれば案

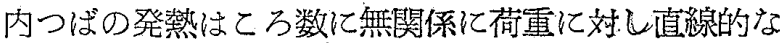
傾向を示して扣り，発熱量は四すい部の約 I0分の1 である。てれに対し円すい部の場合はその特性泣前述 の摩擦特性曲線沉きわわて近い形を示して扣り，荷重 の平方根に比例すると見るてとができる。

この例に従えば変曲点の荷央が第 3 図のものに比心゙ 小さいが，とのととは変曲点が弾性限界に㨟いて起る， こゆう推定に何ら矛盾するものでない。すなわちころ と円すい部の接触か浣全にてろの全長にわたり均等分 布をしていると仮定すれば，弾性限界は完全に素材の それに一致しなければならないが，軸受の加工精度が 低い場合は必ずしも全長にわたる接触が期待できず， したがって弾性限界の見掛け上の值が理論值をはるか に下回ることは当然である。第14四はこのととを確か めるため 4 個の軸受についての摩擦特性を測定した結 果であるが，明らかに変曲点の值が変動しているのが 認められ，いずれも第3図のものに比べ低い变曲点を 示している。このてとは軸受内部の接触長さがこれら の軸受に捛いてはきわめて短汃いととによるものと考 えられ，曲䠌(亿打いては接触長さが最も短かく $A^{\prime}$ で急に塑性変形の起ったもの；(3)は塑性変形が進むに 従って新らしい接触の起ったと考えられるもの，(2は 同しく荷重の増加ととも塑性变形が少部分で除々に 発生しつつあるものと説明することができる。またて ろがり摩擦の理論8に従忩ば弾性限界内に扔いて同一 荷重の下ではその摩擦は円筒の

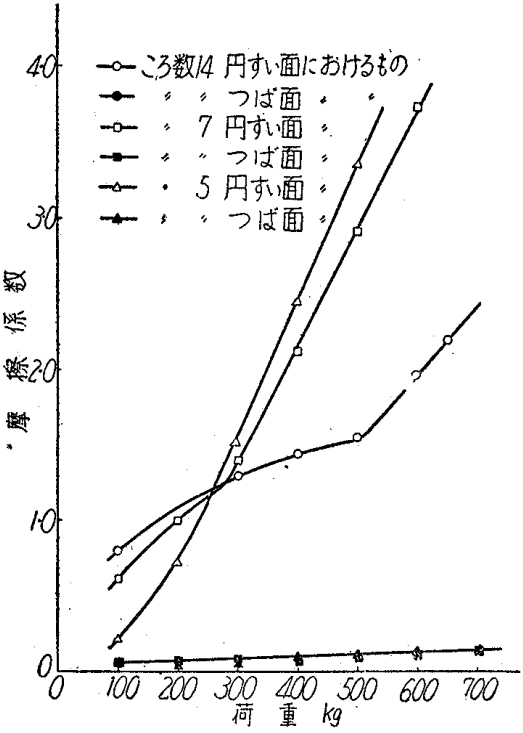

第 13 図

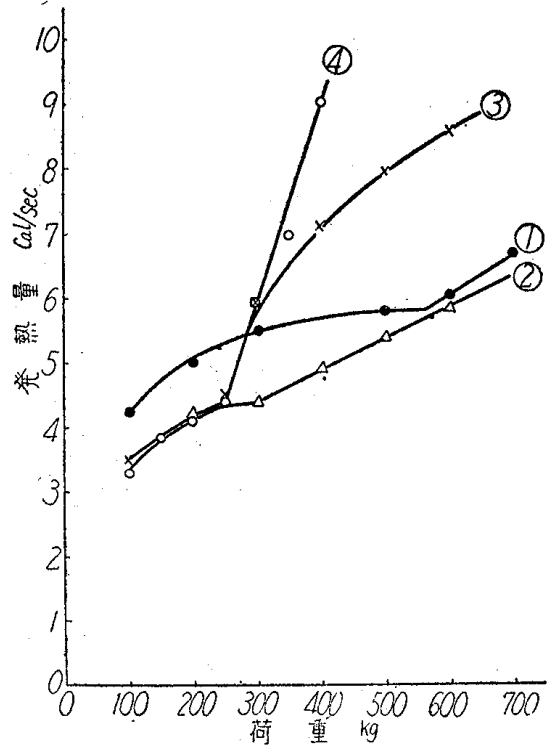

第 14 図 接触長さの平方根に比例すると 考えられるが，(1)(2)ものが弾 性領域内に扣いて明らかに高い 摩擦損失を示して打り，てらの. 挍触長さが長いと推定した上記 の説明に対して傾向的によく一 致しているととがわかる。

\section{3. 結}

以上述べるでとくズラスト荷: 重下に打ける円すいてろ軸受の。 ころのた扣れは，軸受の摩擦に きわわて大きい影響を及ぼして いるととは明らかであるが，て れ付詨する対策については今後 
の研究に待つものが多い、これに民し頭初懸念してい た案内つば部のすべりの影響は大した量ではない。し かし軸受が高速回転で運転される場合，すべり部分の 影響はきわめて大きいとと方溶易仙想像され，てろの 倒れを考慮にいれた場合のつばとてろ端面の安定した 接触を得るようにするための設詿批状を求めることは きわめて困難である。したがってつば部とてろ端面の 表面精度を故意に荒くして回転による早期のなじみを 期待する方法等についても考元直して見る必要があり
そうでありなな゙が起り易くなるための初期の形 状(12)ももち万ん考光られなければならない。

との研究は前機械試験所長佐々木栄一氏の研究訫画 に基づいて行われたものであり，特に早大鈴木敉授か ら細部にわたる御指導，御検討をいただいたてとに対 し深甚の謝意を表させていただく㳄第である。

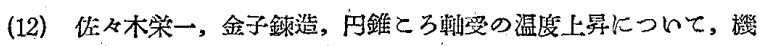

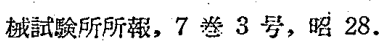

新製品紹介

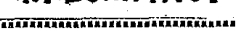

621.9 .025

特許第 168144 号

\section{タンガ口イ特金カッタ}

\section{用}

途

「タンガロイ特金カッタ」は鋼類などのでとく，比較 的高抗張力をもつ被削材あるいは強しんなる連続切り

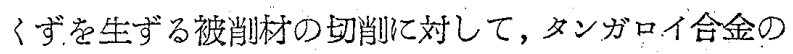
特性をいかした高精能を発揮し得るるうに，特別な着 想仗より設訐製作されている正面フライスである。

したがって在来広く菿及されている当社製「フルバ ックカッタ」は主として踳物類に，本「特金カッタ」 を銅類にと碰用されるととにより，より以上の成果が 収められることと信ずる。

\section{特徽}

（1）ブレードの稙え方：困に示すでとくブレードの カッタ取付軸化対するすくい侮，(Axial Rake Angle) が筫倩なるごとく，加吣付するすくい角 (Radial Rake Angle)が正危なるでとくカッダボディーにブレ 一ドを植えてある.

本カッタ就したがって比較的強度の乏しい刃先先端 部から切込まずして，比輘的強度に富んだ切刃中間部 から切削を開始するととになり，フライス切削固有の

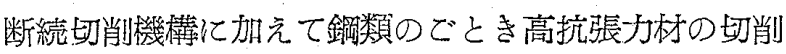
により生ずる大なる衝撃を含虽切削荷雷に十分耐え る。

（2）刃数秄よび切りくず室：ブレードの数すなうう 义数住カッタ称呼直径のインチ数と同数である（例 6 in カッタの場合注刃数は 6).

刃数が一般フライスに比べて少いのでブレードの断 面積せ十分大きくとってあり，功ブレード背面をさ さえるボディー部分も十分強固に設訐してある. 更に 鐦類のでとく切削される幅とほぼ同等の長さの切りく

\section{タンガロイ工業株式会社}

ずを生じても，てれらがカッタと工作物との間侸ま るととがないよう十分広い切りくず公設けてある。

（3）その他：特金カッ夕赔鋼切削を目的としたので タンガロイチップは原則として $\mathrm{S}$ 種を用いてある。 ブレードの切刃長さ招よび切对形状山重切削ができ るように十分長く，かつ適当な Bevel Angle を附し た四刃備えて扣る。

\section{標集型の種類と所要ブレードおよびアーバー}

\begin{tabular}{|c|c|c|c|c|}
\hline \multicolumn{2}{|c|}{ 型番種䣔 } & 㨁径 in & 所要ブレード想番 & アーバー番朚 \\
\hline \multicolumn{2}{|c|}{ 404 R あるいは L } & 4 & BT 4Rあるいは L & A. 04 \\
\hline 405 & $"$ & 5 & BT 5 Rあるいは L & A 05 \\
\hline 406 & $"$ & 6 & $"$ & A 06 \\
\hline 408 & " & 8 & $"$ & C 01 \\
\hline 410 & ” & 10 & " & $"$ \\
\hline 412 & " & 12 & " & $"$ \\
\hline 414 & $"$ & 14 & $"$ & $"$ \\
\hline 416 & " & 16 & " & " \\
\hline 418 & " & 18 & $"$ & $"$ \\
\hline 420 & $"$ & 20 & $"$ & ” \\
\hline
\end{tabular}
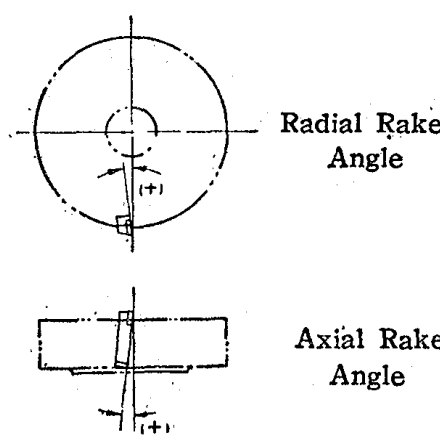

Axial Rake Angle

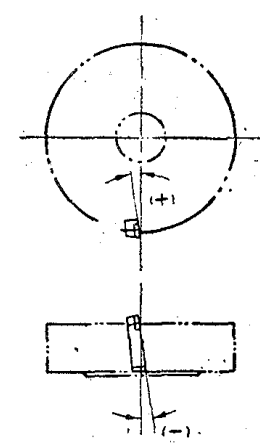

フルパツクカツタの昜合 特金カッ夕の場合

第 1 叉 